\title{
Assessment of Intra-Seasonal Variability and Trends of Precipitations in a Climate Change Framework in West Africa
}

\author{
Daniel Bio Tore1,2, Adechina Eric Alamou, 1,2,3, Ezéchiel Obada, 1,2, \\ Eliezer Iboukoun Biao1,2,4, Esdras B. Josué Zandagba ${ }^{1,2}$
}

\author{
${ }^{1}$ Laboratoire de Géosciences de l'Environnement et Applications, Université Nationale des Sciences, Technologies, Ingénierie et \\ Mathématiques (UNSTIM), Abomey, Benin \\ ${ }^{2}$ Laboratoire d'Hydrologie Appliquée (LHA), Institut National de l'Eau, Université d'Abomey-Calavi (UAC), Godomey, Benin \\ ${ }^{3}$ École Nationale Supérieure des Travaux Publics (ENSTP/UNSTIM), Abomey, Benin \\ ${ }^{4}$ École Nationale Supérieure de Génie Mathématique et Modélisation (ENSGMM/UNSTIM), Abomey, Benin \\ Email: biot275@gmail.com, ericalamou@unstim.bj, obada.ezechiel@unstim.bj, \\ biaoeliezer@unstim.bj, zandagbajosue@unstim.bj
}

How to cite this paper: Tore, D.B., Alamou, A.E., Obada, E., Biao, E.I. and Zandagba, E.B.J. (2022) Assessment of Intra-Seasonal Variability and Trends of Precipitations in a Climate Change Framework in West Africa. Atmospheric and Climate Sciences, 12, 150-171.

https://doi.org/10.4236/acs.2022.121011

Received: November 11, 2021

Accepted: January 25, 2022

Published: January 28, 2022

Copyright $\odot 2022$ by author(s) and Scientific Research Publishing Inc. This work is licensed under the Creative Commons Attribution International License (CC BY 4.0).

http://creativecommons.org/licenses/by/4.0/ (c) (i) Open Access

\begin{abstract}
Climate change has led human beings to take an interest in the study of meteorological and climatic phenomena. In fact, the main impact of climate change on different sectors of society is caused by extreme events since the occurrence of extreme events leads to more impact related to change in mean climate. Unfortunately, the West African region is vulnerable to extreme rainfall impact because its economy is based on rain-fed agriculture. This study examined the seasonal variability of extreme rainfall in West Africa. Eight (8) climate indices were chosen from among the 27 defined by the Expert Team on Climate Change Detection and Indices (ETCCDI). The nonparametric Mann-Kendall test was used to assess the seasonal trends. The indices of the same types (frequency or intensity) were compared to assess the intra-seasonal variation of extreme precipitation. The results indicate that, regardless of the season, the Gulf of Guinea receives more rainfall than the Sahel. This phenomenon is due to the fact that the coastal part of West Africa is under the influence of evaporation which is observed at the Atlantic Ocean and during the monsoon, while the other part is dominated by the desert. Mann-Kendall's test revealed upward and downward trends during each season. The increase in extreme rainfall trends in the number of consecutive dry days suggests that droughts, due to global warming, could be observed and could have severe consequences in terms of water availability, energy supply, agricultural yields and ecosystems in West Africa. In addition, it can lead to the loss of biodiversity and health issues. It is therefore essential for policy-
\end{abstract}


makers or decisions makers to determine strategies and mitigation measures against climate change and its impacts on populations.

\section{Keywords}

Extreme Precipitation, Indices, Variability, Trend, Mann Kendall, West Africa

\section{Introduction}

The reality of climate change is no longer a secret but rather a major problem of our century that threatens several development sectors. This situation has led man to take an interest in the study of meteorological and climatic phenomena. Thus, the increase of droughts, floods or hurricanes frequency and intensity, has made the deepening of the study of the climate and its variations very topical and encourages the scientific community to intensify its efforts in order to identify changes on a global scale [1]. Recent agreement on the increase in rainfall, since the end of the 1990s some scientists [2] [3] [4] [5], showed that the mean rainfall of the decades from 1970 to 2009 remained lower than the decades from 1900 to 1970. Moreover, some authors found an intensification of rainfall regime in the Sahelian region since 2000, characterized by a greater contribution of extreme precipitation to the annual total rainfall [6] [7]. Future projections of the global climate predict an intensification of average warming, in addition to the variability of precipitation and also a frequency and intensification of extreme events [8]. It is also the case of many climate projections which have shown that West Africa will experience a significant increase in temperatures associated with high variability in rainfall [9] [10]. As for trends, extreme precipitation indices have been observed on a large scale [11], in Europe [12] [13], in South America [14], in Asia [10] and in West and North Africa [15].

It was shown in [8] that Africa is among the most affected areas due to its constantly increasing population and a lack of adequate adaptation strategies [16]. West African region is also vulnerable to extreme rainfall impact because its economy is based on rain-fed agriculture [17]. For example, in the 1970s and 1980s, West Africa is experienced severe droughts which caused enormous economic loss due to the decline in agricultural production, loss of livestock and lower production of hydroelectric power, etc. After this period of drought, a resumption of precipitation is observed with an increase in the intensity and frequency of daily extreme rainfall in the decades 2000 and 2010 [17]. This led to an increase in the frequency and intensity of floods and cause material and human damages. The main impact of climate change on different sectors of society is caused by extreme events since the occurrence of extreme events leads to more impact related to change in mean climate [18]. Considering the effects of climate change on water resources, food security and ecosystems in West Africa, current fluctuations in the rainfall regime need to be mastered in order to assess the fu- 
ture rainfall dynamics. The study of the regional climate of West Africa takes part in the major international issues, in the articulation between the understandings of the evolution of the climate, the societal challenges to the populations and to the decision-makers to face global changes. This is the reason why the variability of climate has been the subject of several studies in West Africa [7] [19]-[24]. However, most of the investigated previous research studies were limited to the analysis of annual or monthly rainfall data. [25] showed that in the West African region, precipitation is characterized by high variability in both interannual and decadal scale. The same region experienced the strongest fluctuation in intra-seasonal precipitation during the second half of the $20^{\text {th }}$ century [26] [27].

The present research study aims to identify seasonal climate changes in West Africa. Specifically, the work consists in analyzing the intra-seasonal variability of extremes rainfall indices. The study of extreme rainfall and its evolution over West Africa is very important for the implementation of operational management of flood, drought, food security, risk, mitigation policies, which are currently under-developed in this country.

\section{Materials et Methods}

\subsection{Presentation of the Study Area}

West Africa is located between latitude $4^{\circ} \mathrm{N}$ and $28^{\circ} \mathrm{N}$ and longitude $17^{\circ} \mathrm{W}$ and $16^{\circ} \mathrm{E}$, covering a total area of 6 million $\mathrm{km}^{2}$. The seasonal oscillation of the inter-tropical convergence zone in the north-south direction of West Africa defines the climate zones [28] because it determines the amount of précipitations that each climate zone obtains annually. The Köppen-Geiger climate zones of West Africa [29], which occur in the latitudinal strata as shown in Figure 1 are: the equatorial monsoon zone, the equatorial winter and arid desert zone. Annual precipitations across these different areas are relatively constant by following longitude, but decrease from south to north. The description of the climate system is presented in relation to the general atmospheric circulation of which it constitutes an important component [30]. The atmospheric equilibrium is maintained through this general circulation. The West African climate mechanism is mainly based on the soil-atmosphere-ocean interaction which determines the dynamics within the intertropical convergence zone (ITCZ) over the region [31].

\subsection{Data}

Data used consist of observed and satellite dataset of CPC Global PRCP V1.0; (https://www.Esrl.noaa.gov/psd/data/gridded/data.cpc.globalprecip.html). It is a daily gridded precipitations dataset with $0.5^{\circ}$ longitude $\times 0.5^{\circ}$ latitude spatial resolution. It covers the period from 1980 to 2018.

Eight (8) indices of extreme rainfall indices defined by the Expert Team Monitoring on Climate Change Detection and Indices (ETCCDI) [32] were investi- 
gated. These indices capture not only the intensity and duration of changes in rainfall, but also the frequency of heavy precipitation events. The investigated extremes climate indices are showed in Table 1.

These indices are on a daily time step and ETCCDI have proposed a set of climate indices enabling comparison accross different regions [33] [34] [35]. The advantage of using these indices in detecting climate change is that they can be applied to different climate parameters such as minimum temperatures, maximum temperatures and precipitations at daily time step. They are easily understandable and manageable for studies of climatic impacts on the socio-economic

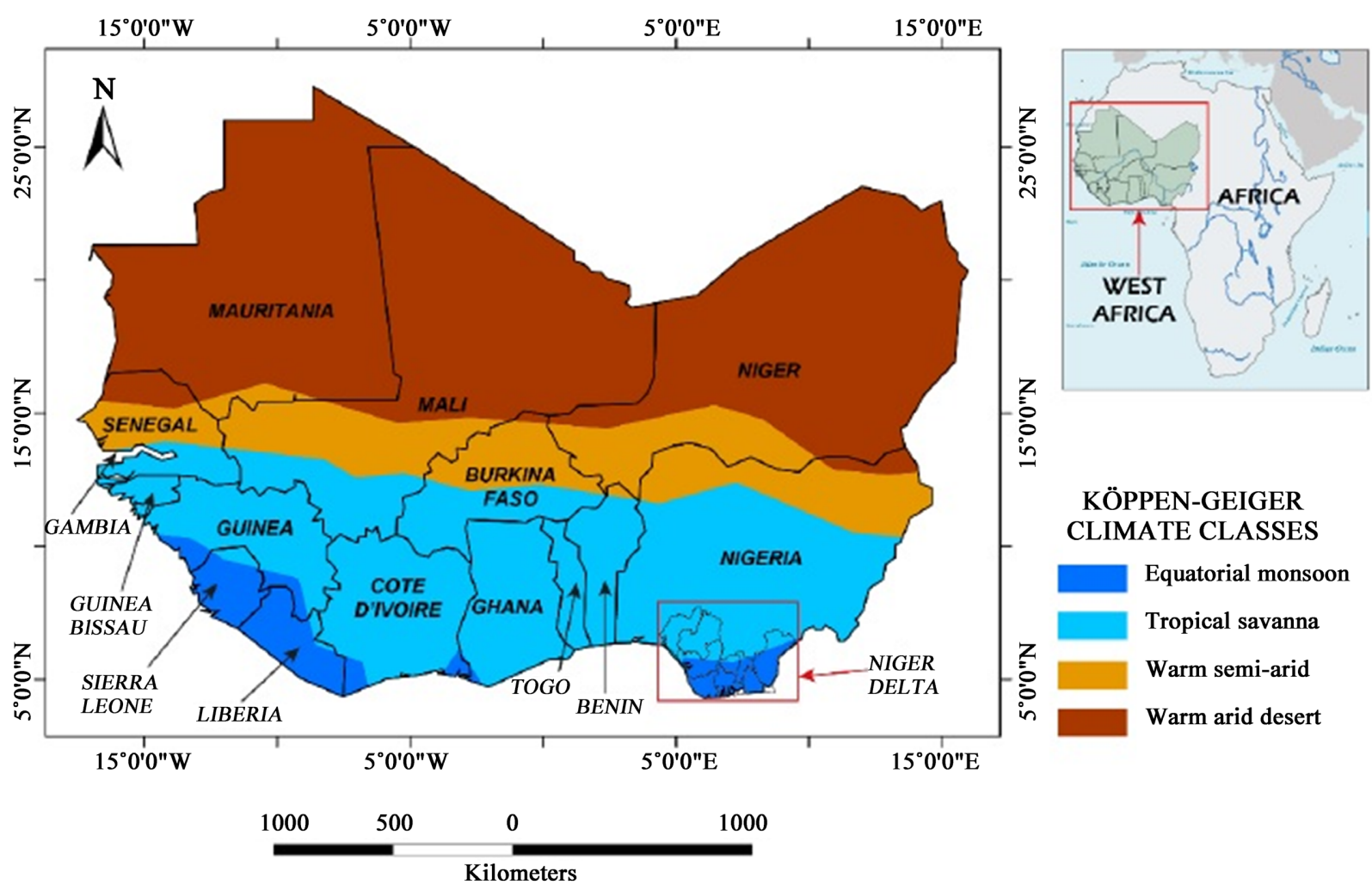

Figure 1. Map of West Africa showing the climatic zones.

Table 1. Precipitation indices used in the study.

\begin{tabular}{cccc}
\hline Indice & Descriptive name & Definition & Units \\
\hline P & Annual precipitation total of wet day & Annual total precipitation for wet day & mm \\
R1 & Number of wet days precipitation & Annual count of days when $\mathrm{R} \geq 1 \mathrm{~mm}$ & days \\
CDD & Consecutive dry days & Maximum number of consecutive dry days & days \\
CWD & Consecutive wet days & Maximum number of consecutive wet days & days \\
R20 mm & Very heavy precipitation days & Annual count of days when RR $\geq 20$ & days \\
SDII & Simple daily intensity indiex & Average precipitation on wet days & mm/day \\
RX1day & Maximum 1-day precipitation & Annual maximum 1-day precipitation & mm \\
Rx5day & Maximum 5-day precipitation & Annual maximum consecutive 5-day precipitation & mm \\
\hline
\end{tabular}


level [36] [37]. In this study, we analyzed eight (08) extreme précipitations indices defined by ETCCDI. Some of them are based on fixed thresholds which are the same for all stations. Details of the indices are presented in Table 1.

\subsection{Methods}

The characterization of the seasonal variability in West Africa is made over the period 1980-2018 through an analysis of the average and the trend of the investigated extreme rainfall indices. To achieve this goal, we use Mann Kendall test to assess seasonal trends in the study area.

Mann-Kendall test is a non-parametric test commonly used to detect monotonic trends in the series of meteorological, hydrological, environmental data, etc... [38] [39] [40]. The main advantages of Mann-Kendall test are the low sensitivity in homogeneous time series [41] and the non-requirement of normal distributed time series since the test is non-parametric (distribution-free test). The null hypothesis (H0) shows no trend in the series and data, which come from an independent population, are identically distributed. The alternative hypothesis (H1) indicates that the data follow a monotonic trend (upward or downward trend). It is calculated following these equations.

$$
S \equiv \sum_{i=1}^{n-1} \sum_{j=i+1}^{n} \operatorname{sign}\left(x_{j}-x_{i}\right)
$$

where $x_{i}$ and $x_{j}$ are the annual values in years $i$ and $j, j>i$ and

$$
\operatorname{sign}\left(x_{j}-x_{i}\right) \equiv \begin{cases}1 & \text { if } x_{j}-x_{i}>0 \\ 0 & \text { if } x_{j}-x_{i}=0 \\ -1 & \text { if } x_{j}-x_{i}<0\end{cases}
$$

The mean of $S$ is $E[S]=0$ and the variance of $S$ is computed by Equation (3)

$$
\operatorname{VAR}(S)=\frac{1}{18}\left[n(n-1)(2 n+5)-\sum_{p=1}^{q} t_{p}\left(t_{p}-1\right)\left(2 t_{p}+5\right)\right]
$$

where $n$ is a number of data points, $q$ is the number of tied groups and $t_{p}$ is the number of data values in the $p^{\text {th }}$ group.

Normal approximation ( $Z$ statistic) is generally used when the sample size is more than 10. $Z$ statistic is given by Equation (4).

$$
Z= \begin{cases}\frac{S-1}{\sqrt{\operatorname{VAR}(S)}} & \text { if } S>0 \\ 0 & \text { if } S=0 \\ \frac{S+1}{\sqrt{\operatorname{VAR}(S)}} & \text { if } S<0\end{cases}
$$

A positive $Z$ value denotes increasing trend, while a negative $Z$ value indicates decreasing trend. At $\alpha$ level of significance, (H0) is rejected if the absolute value of $Z$ is greater than $Z_{1-\alpha / 2}$, where $Z_{1-\alpha / 2}$ is obtained from the standard cumulative distribution tables [42]. 


\section{Theil-Sen's slope}

The magnitude of a trend was also assessed by using the Theil-Sen's estimator. This slope is a robust estimation of the magnitude of a trend [38] and it is calculated as following (Equation (5)):

$$
b=\text { median }\left(\frac{x_{j}-x_{i}}{t_{j}-t_{i}}\right)
$$

where $x_{i}$ and $x_{j}$ are respectively the variable values at times $t_{i}$ and $t_{j}$.

\section{Results and Discussion}

\subsection{Seasonal Variability of Extreme Rainfall Indices}

\subsubsection{Intensity Indices}

Figure 2 presents the seasonal interannual averages of rainfall $(\mathrm{P})$ and the simple daily intensity index (SDII) over the period from 1980 to 2018. It can be seen from this figure that, whatever the season, the Gulf of Guinea is more watered than the Sahel region. This is due to the fact that the south of West Africa is a coastal part and is therefore under the influence of evaporation observed in the Atlantic Ocean during the monsoon, while the north is dominated by the desert. The rainfall amounts for the JJA (June-July-August) and SON (September-October-November) seasons are the highest. Indeed, they vary respectively from 0 to approximately $1500 \mathrm{~mm}$ for JJA and from 0 to $1000 \mathrm{~mm}$ for the SON season. The rainfall amounts for these two seasons actually represent the rains of the West African monsoon. From all of the above, it emerges that there is a decrease in the average daily rainfall and also a rarity of rainfall events depending on the monsoon season.

Regarding the simple daily intensity index, they are also high in the South and
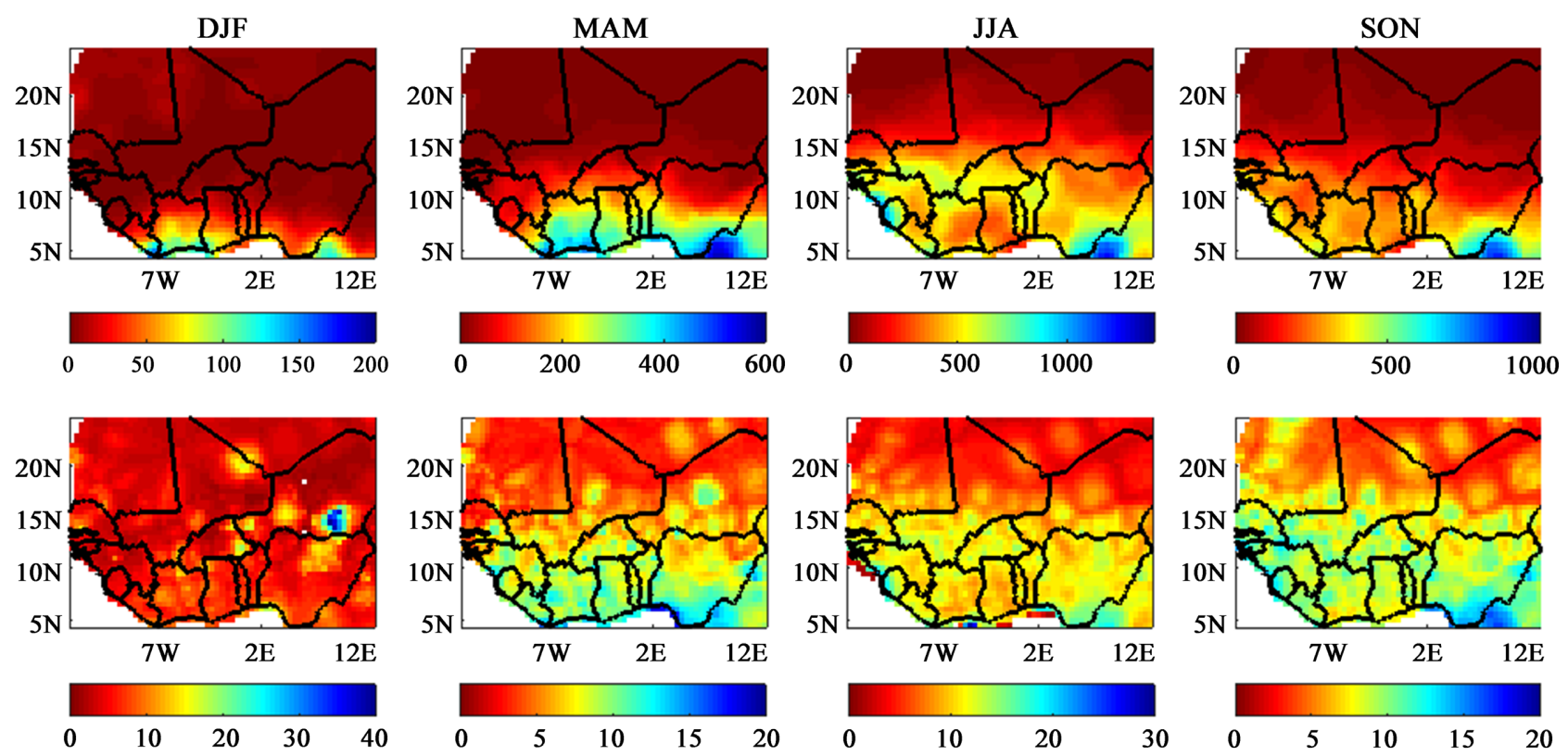

Figure 2. Seasonal interannual average of rainfall (line 1) and simple daily intensity index (line 2). 
low in the North. These indices have also a seasonal distribution similar to the observed rainfall. The highest SDII of about 15 to $20 \mathrm{~mm} /$ day is found in coastal region on MAM (March-April-May), JJA and SON seasons. A cross-analysis of these two indices shows that the increase in precipitation is more systematic in the southern part of West Africa during the JJA and SON seasons. It follows that the changes in the intensity of precipitation correspond to the spatial evolution of the number of rainy days from the north to the south of this area of West Africa.

Figure 3 shows the seasonal interannual averages of maximum 1-day precipitation (Rx1day) and maximum 5-days precipitation ( $\mathrm{Rx} 5$ day). As Figure 1 , it is showed that for these two indices, the values are higher in the South than in the North. The maximum rainfall amount in one day are obtained during the JJA season followed by the SON and MAM seasons (March April May). During this season, Rx1-day varies from 0 to $100 \mathrm{~mm}$ /day. Regarding the Rx5-days, the SON season has the highest values, followed by the DJF (December-January-February) and JJA seasons. Although JJA is the main rainy season in West Africa, Rx5-days are lower than those of the SON season, as they vary from 0 to $140 \mathrm{~mm}$.

\subsubsection{Frequency Indices}

Figure 4 shows the seasonal interannual averages of number of wet days and Number of very heavy precipitation days. Whatever the season, the number of wet days and very heavy precipitation varies according to the latitude. It is higher in the South and lower in the North. Regarding the number of wet days, the JJA season has the highest number of wet days which varies from about 60 days in the South to 0 in the North. The SON and MAM season follow with values ranging from 50 days to 0 and 40 days to 0 respectively. The DJF season has the smallest number (roughly equal to 0 ) of rainy days in the region.

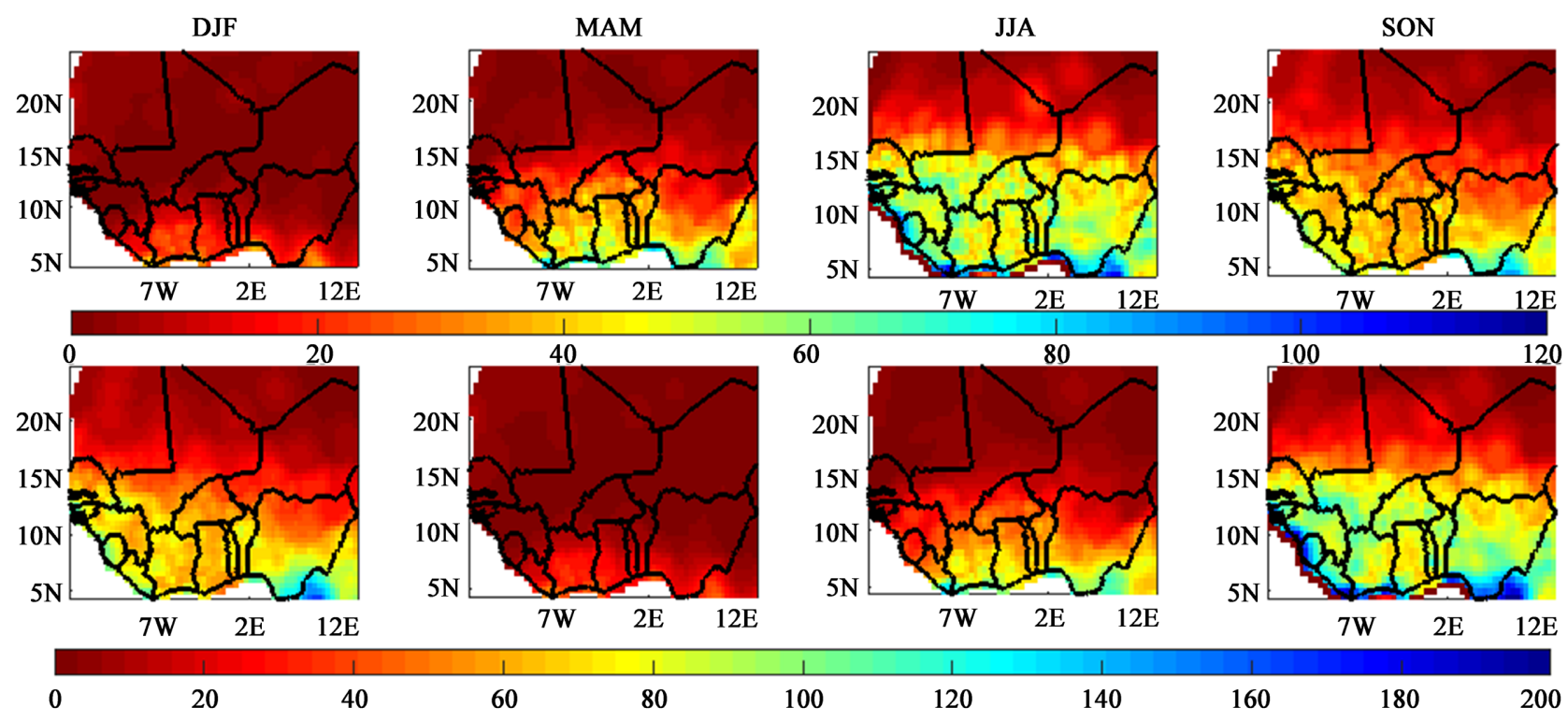

Figure 3. Seasonal interannual average of Rx1day (line1) and Rx5day (line 2). 
The same is observed with the number of very heavy precipitations days, which varies respectively from about 20 days to 0 during the JJA season, 15 days to 0 during the SON and MAM seasons. This number is practically 0 day for the DJF season.

Figure 5 shows the interannual averages of consecutive dry days (CDD) and the consecutive wet days (CWD) in West Africa over the period 1980 to 2018. Consecutive dry days decrease, regardless of the season, from the North to South. The Consecutive dry days of MAM season varies from around 60 to 90 days, while for the JJA and DJF seasons, it is low in the South and varies between 0 and 41 days. The SON season is the one which contains the weakest consecutive
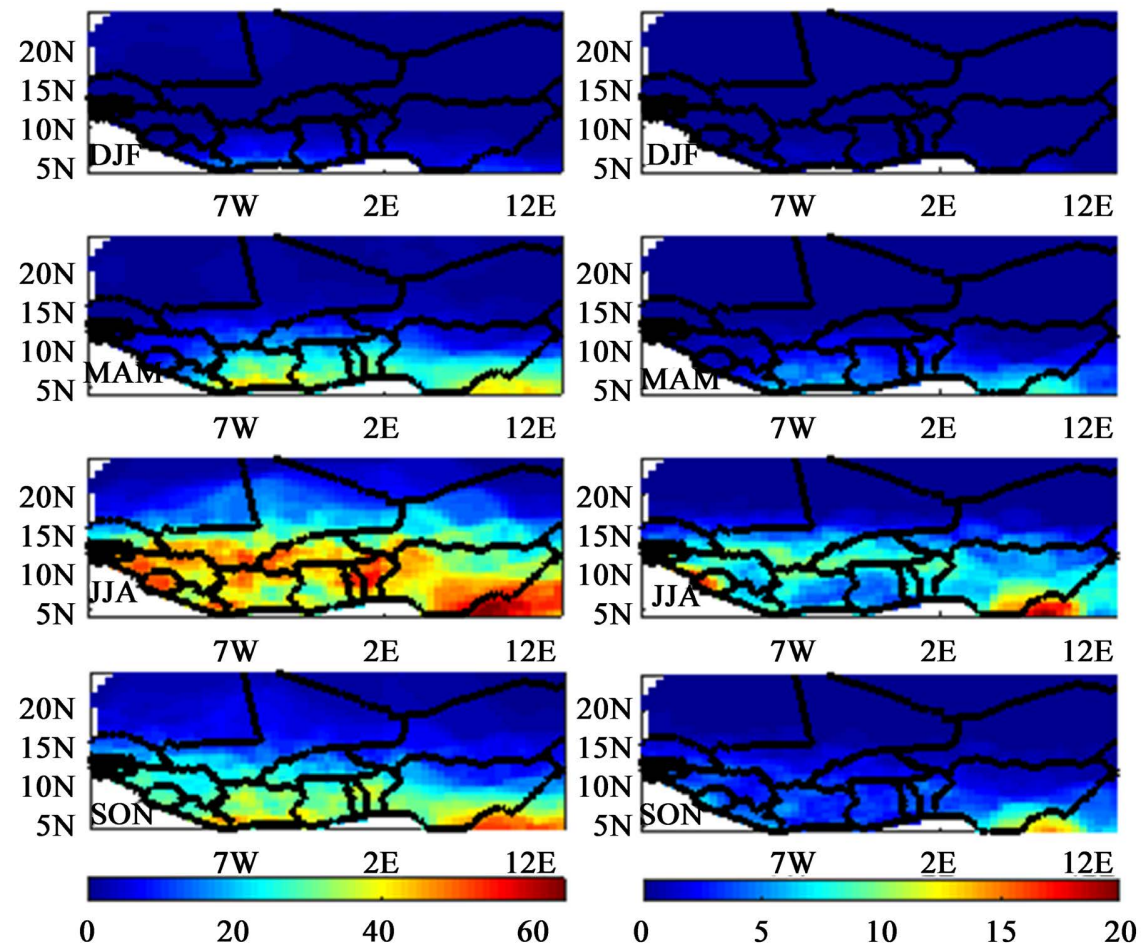

Figure 4. Seasonal interannual mean of number of wet days (column 1) and number of very heavy precipitations days (column 2).
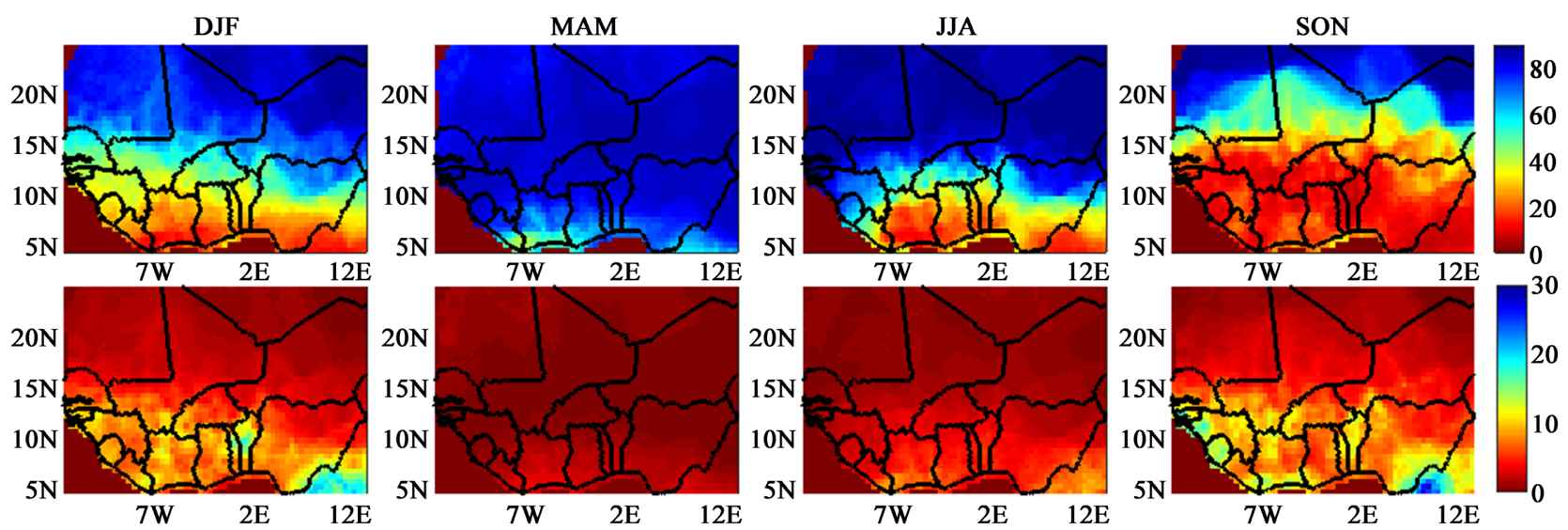

Figure 5. Interannual seasonal average of CDD (column 1) and CWD (column 2). 
dry days, especially between latitudes 5 and $20^{\circ} \mathrm{N}$ with values between 0 and 30 days.

The consecutive wet days have an opposite direction of variation on the latitude. The SON and DJF seasons have the high consecutive dry days.

The duration of the consecutive dry days within the rainy season is therefore increase from the costal regions to the Sahara, confirming the irregularity of the rainfall regime in West Africa.

\subsection{Trends in Extreme Rainfall Indices in West Africa}

\subsubsection{Intensity Indices}

Figure 6 shows seasonal trends of annual precipitation over West Africa. This figure indicates a mix of positive and negative seasonal trends over West Africa. These trends are between $-1.25 \mathrm{~mm} /$ year and $2 \mathrm{~mm}$ /year for DJF season, while for MAM, it is between $-7.5 \mathrm{~mm} /$ year and $6 \mathrm{~mm} /$ year. For JJA, trends vary between $-15 \mathrm{~mm} /$ year and $25 \mathrm{~mm} /$ year, while for SON season they are between $-10 \mathrm{~mm} /$ year and $15 \mathrm{~mm} /$ year. During the DJF and MAM seasons, downward trends are mostly found over West Africa. These trends are significant for DJF season over Mauritania, Sierra Leone, Southern of Nigeria, Southeasten of Niger, while for MAM season significant trends are only found in costal region between $5^{\circ} \mathrm{N}$ and $12^{\circ} \mathrm{N}$. Increase trends are detected mostly in the coastal regions, such as southern of Liberia, Ivory Coast, Ghana, Nigeria, Middlewest Cameroon for DJF season, while increase trends are found in middle of Nigeria, Malia, middle of Cameroon.

JJA and SON seasons are marked by increase trends over West Africa. These
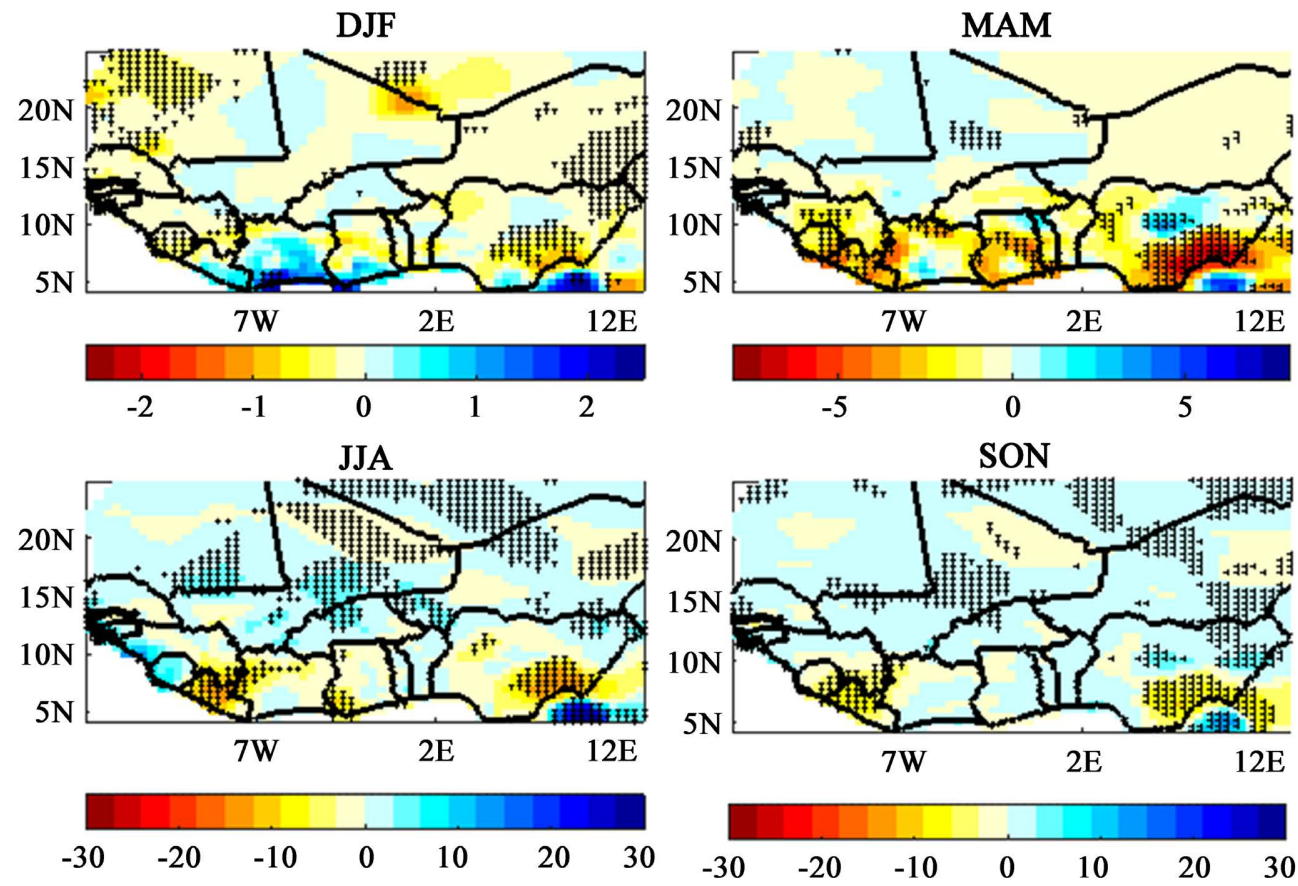

Figure 6. Trends in seasonal rainfall (mm/year) in West Africa over the period 1980 to 2018. Hatching indicates regions where trends are significant at the $95 \%$ confidence level. 
increasing trends are sometimes significant. However decrease trends are observed for both sesons over Liberia and southern of Nigeria, nothern Malia and northern Niger.

Figure 7 shows seasonal trends of simple daily intensity index (SDII) over West Africa. For all seasons there is a mix of upward and downward trends over West Africa. These trends are between $-5 \mathrm{~mm} /$ year and $5 \mathrm{~mm} /$ year for DJF season, while for MAM, it is between $-2 \mathrm{~mm} /$ year and $1 \mathrm{~mm} /$ year. For JJA, trends vary between $-0.25 \mathrm{~mm}$ /year and $0.5 \mathrm{~mm} /$ year, whereas they are between -0.5 $\mathrm{mm} /$ year and $0.5 \mathrm{~mm}$ /year for SON season.

For DJF, few significant trends were observed over Northern Mauritania, Southern Algeria and Southern Nigeria, while significant increase trends were found over only middle Niger. Few significant trends are observed for MAM. These trends are located mostly in southern West Africa. Negative significant trends cover Northern Ivory Coast and Western Ghana, while positive significant trends are located in middle of Nigeria and northern of Mauritania. For both JJA and SON trends magnitude are very slight and are constituated by spatial mix of increase and decrease trends which are sometimes statistically significant at $95 \%$ confident level.

Figure 8 shows seasonal trends of maximum 1-day precipitation (Rx1day) over West Africa. For all seasons there is a mix of increase and decrease trends over West Africa. These trends are between $-0.5 \mathrm{~mm} /$ year and $0.7 \mathrm{~mm} /$ year for DJF season, while for MAM, it is between $-1 \mathrm{~mm} /$ year and $1 \mathrm{~mm} /$ year. For both JJA and SON, trends vary between $-2 \mathrm{~mm} /$ year and $2 \mathrm{~mm} /$ year.

For both DJF and MAM, statistically significant trends at 95\% confident level
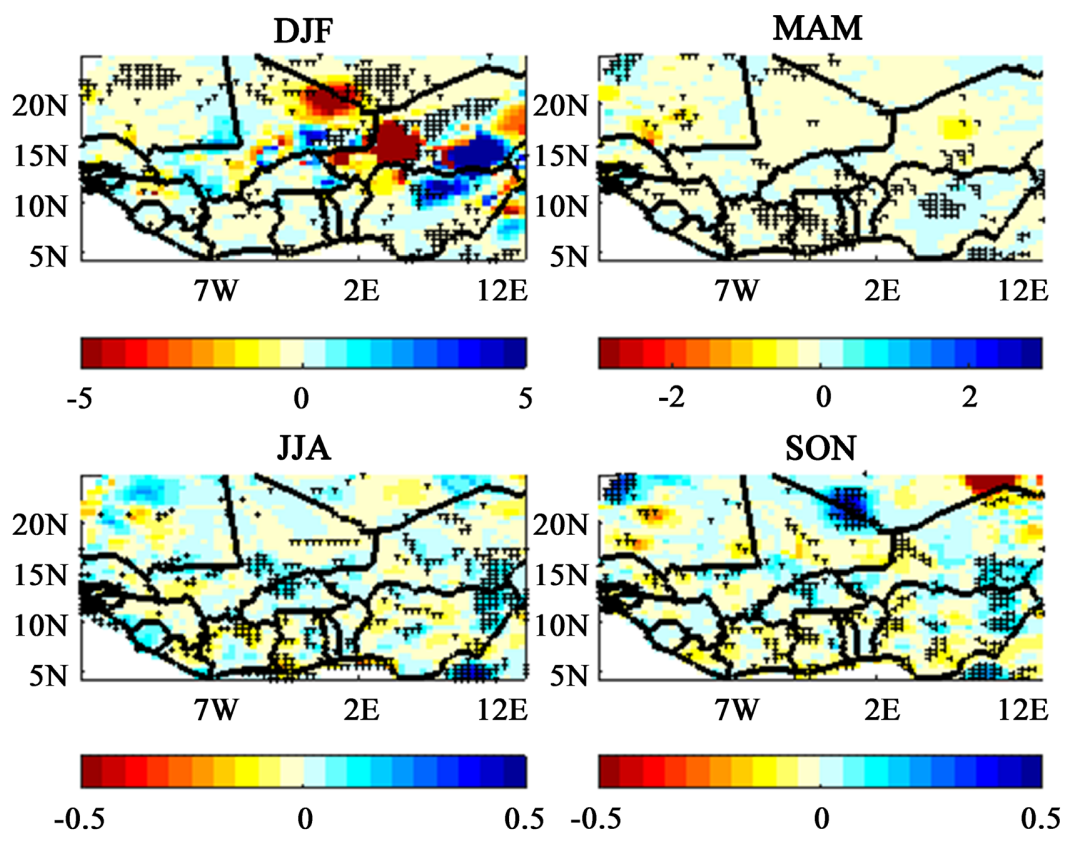

Figure 7. Trends in seasonal simple daily intensity index ( $\mathrm{mm} / \mathrm{year}$ ) in West Africa over the period 1980 to 2018. Hatching indicates regions where trends are significant at the $95 \%$ confidence level. 


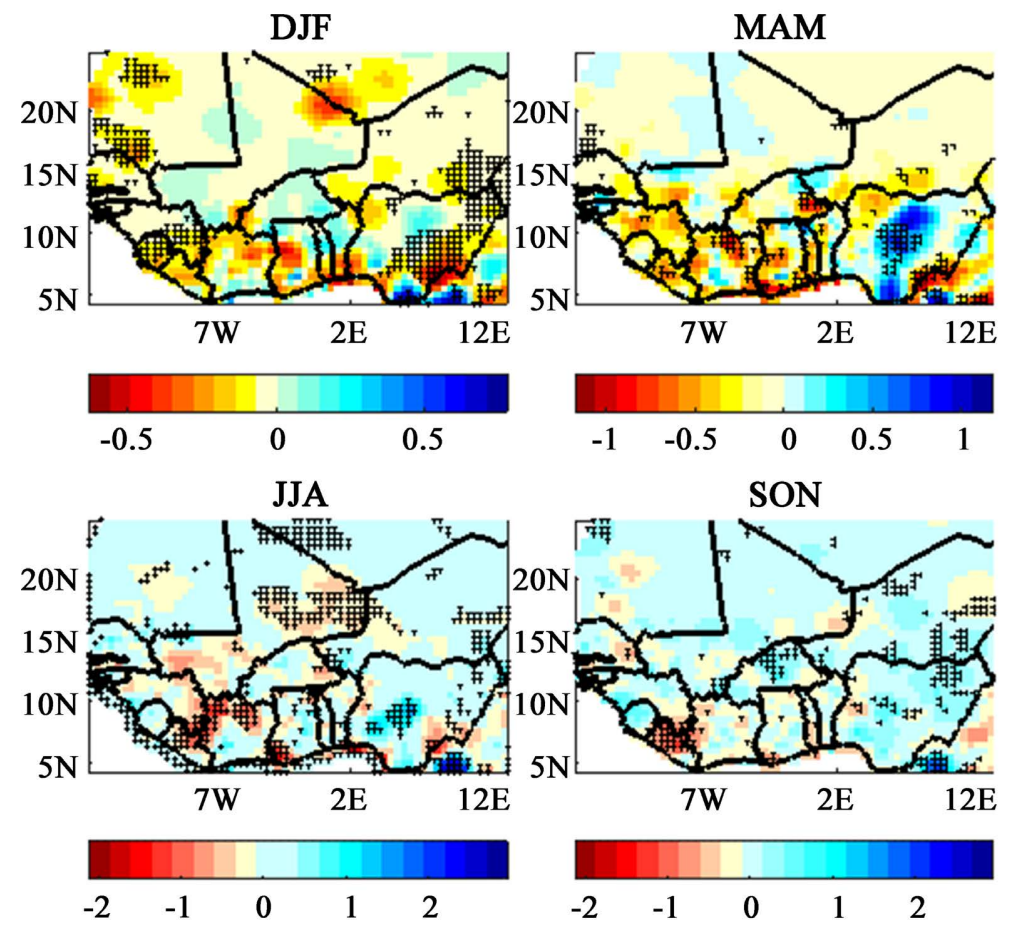

Figure 8. Trends in maximum 1-day precipitation ( $\mathrm{mm} / \mathrm{year}$ ) in West Africa over the period 1980 to 2018. Hatching indicates regions where trends are significant at the $95 \%$ confidence level.

were observed over southern of West Africa. These trends are downward trends excepted over middle of Nigeria where upward trends are observed for MAM season. It is important to notice that the northern West Africa presents only non-significant trends of Rxlday for MAM while some significant downward trends are found over Mauritania. The JJA and SON seasons have the same spatial pattern of trends which are mosly non-significant upward trends. However, some significant decrease trends are observed mosly in southern of West Africa.

Figure 9 shows seasonal trends of maximum 5-day precipitation (Rx5day) over West Africa. For all seasons there is a mix of increase and decrease trends over West Africa. These trends are between $-2 \mathrm{~mm} /$ year and $4 \mathrm{~mm} /$ year for DJF season while for MAM, it is between $-1 \mathrm{~mm} /$ year and $1 \mathrm{~mm} /$ year. For both JJA and SON, trends vary between $-2 \mathrm{~mm}$ /year and $2 \mathrm{~mm}$ /year.

For DJF statistically significant trends at $95 \%$ confident level are mostly observed from the middle to the northern of West Africa, while they are mostly observed from the middle to the southern of the study area for MAM. These trends are downward trends for MAM season, while they are upward for DJF season. The same situation is showed with JJA and SON seasons for which statistical downward trends at $95 \%$ confident level are observed in only southern of West Africa for JJA accepted the upward trends noticed in the middle of Nigeria. For SON season, trends are mostly upward especially in the northern of study area, while the southern presents downward trends over northern of Ivory Coast, Libera, southern of Ghana and Nigeria. 


\subsubsection{Frequency Indices}

Figure 10 shows seasonal trends of number of wet days (R1) over West Africa. For all seasons there is a mix of increase and decrease trends over the study area. These trends are between -1.5 day/decade and 2 days/decade for DJF season, while for MAM, it is between -7.5 days/decade and 5 days/decade. For JJA magnitude, trends between -10 days/decade and 10 days/decade are found, while for
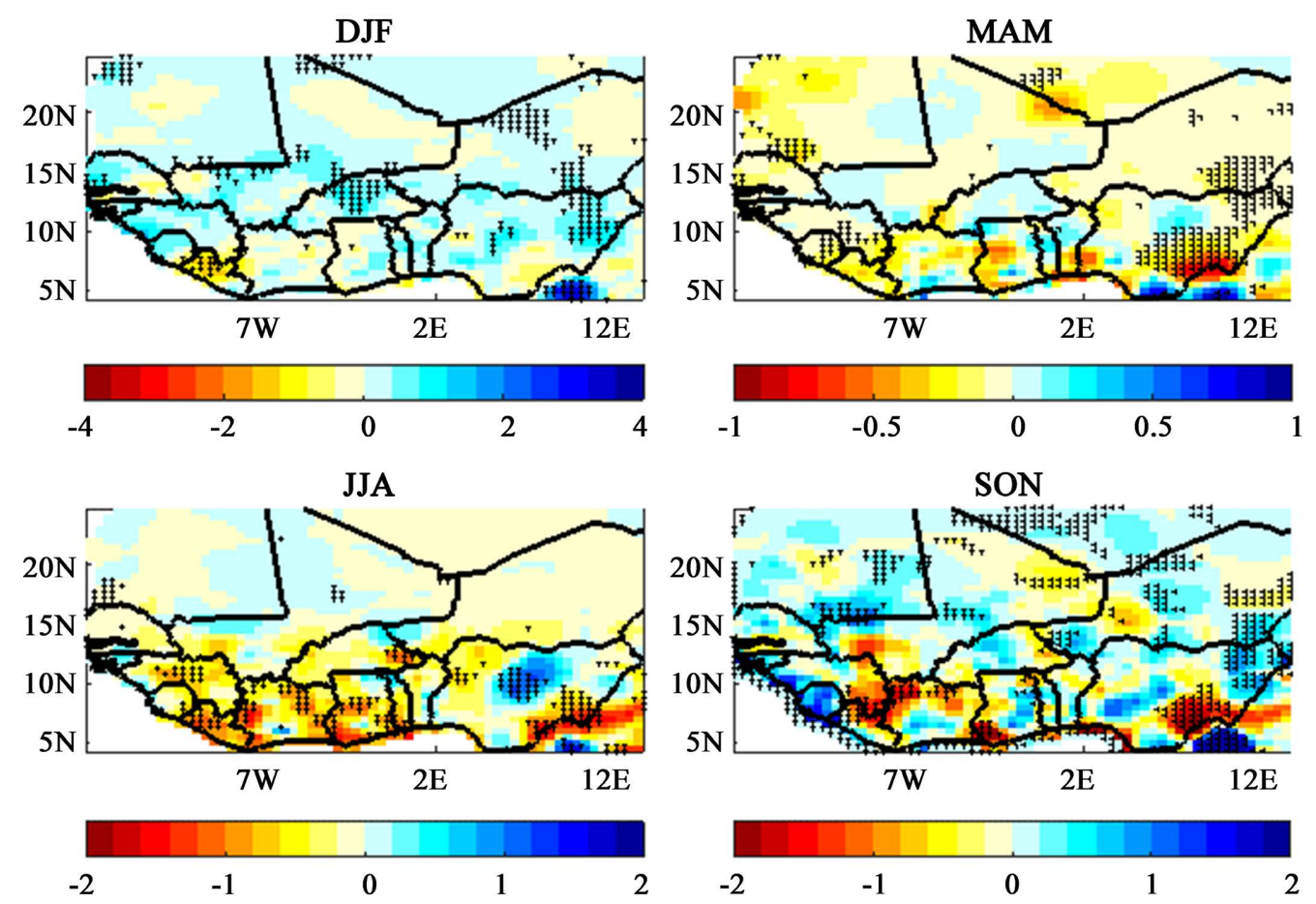

Figure 9. Trends in maximum 5-days precipitation (mm/year) in West Africa over the period 1980 to 2018. Hatching indicates regions where trends are significant at the $95 \%$ confidence level.
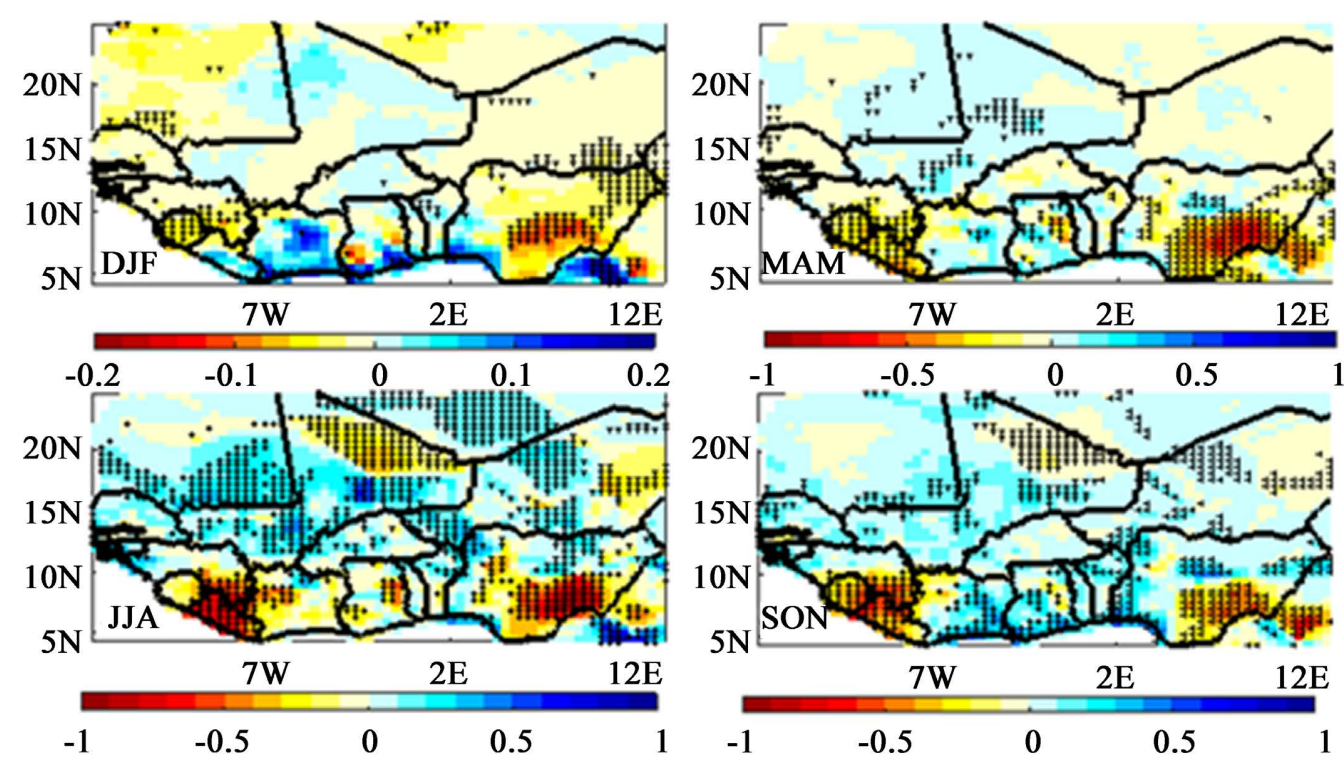

Figure 10. Trends in the number of wet days (days/decade) in West Africa over the period 1980 to 2018. Hatching indicates regions where trends are significant at the $95 \%$ confidence level. 
SON season trends vary between -10 days/decade and 6.5 days/decade.

Over Sierra Leone, Liberia, eastern Guinea and Nigeria, significant decrease trends are observed for both DJF and MAM seasons. The remain part of the study area experienced non-significant increase/decrease trends. For JJA season, trends are statistical signifcant through the whole West Africa, while for SON, significant trends are mostly observed over sourhern of West Africa, excepted over northern Malia and northern Niger, which experienced significant trends. For both JJA and SON, decrease trends are found over southern of West Africa, while over the northern part of West Africa, trends are significantly increasing, accepted in northern Malia and northern Niger.

Figure 11 shows seasonal trends of number of very heavy wet days (R20) over West Africa. For all seasons there is a mix of increase and decrease trends over the study area. These trends are between -0.5 day/decade and 0.6 day/decade for DJF season, while for MAM, it is between -2 days/decade and 1.5 days/decade. For JJA, magnitude trends are between -3 days/decade and 6 days/decade, while for SON season trends vary between -3 days/decade and 4 days/decade.

For DJF season, statistical sgnificant at 95\% confident level upward trends are observed in the Sahel and Sahara, while downward trends are found in Gulf of Guinéa countries which statistically significant over southern Nigeria and Liberia. For MAM, JJA and SON statistically significant upward trends are observed only in the Sahara, excepted for JJA season where statistically significant upward trends are found in Sahel. Over southern West Africa downward trends are observed for the three seasons. Statistically significant at 95\% confident level increase trends are mostly found over southern West Africa for MAM, while for
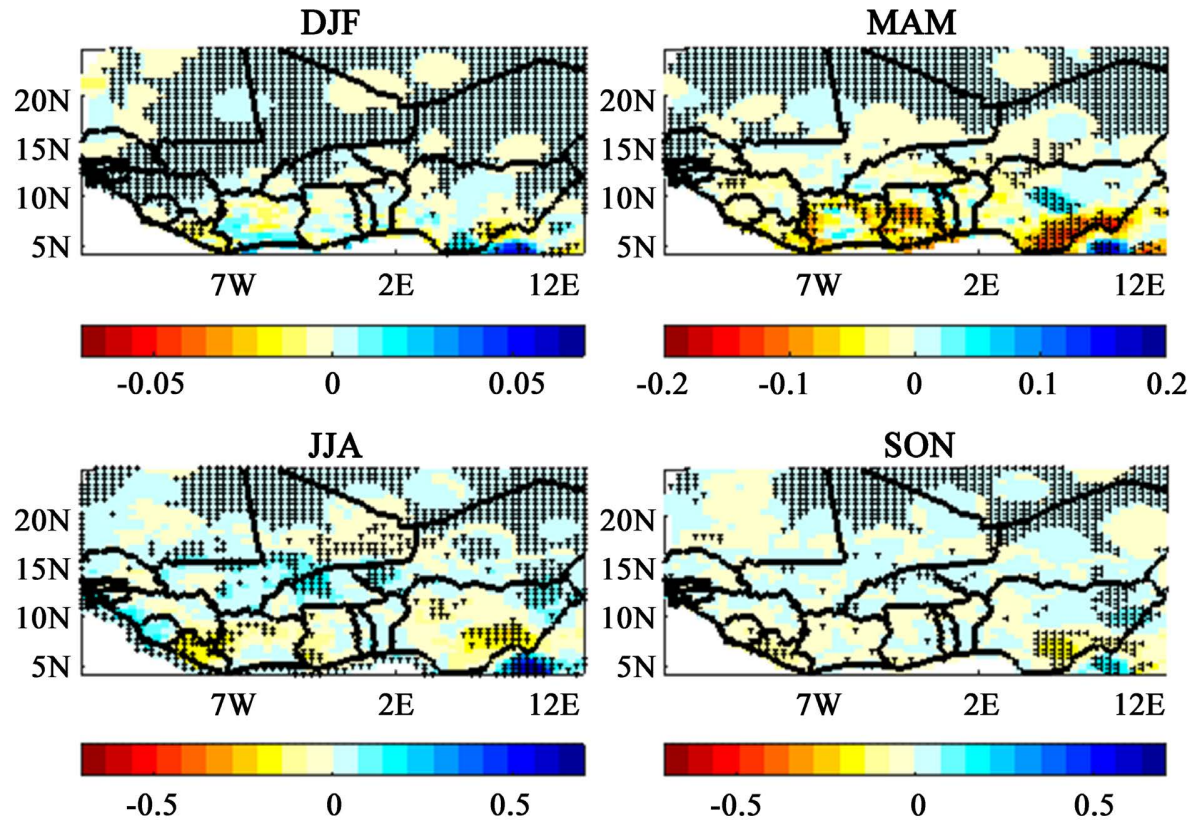

Figure 11. Trends in the number of very heavy wet days (days/decade) in West Africa over the period 1980 to 2018 . Hatching indicates regions where trends are significant at the $95 \%$ confidence level. 
both JJA and SON these increase trends are statistically significant over southern of Nigeria and Liberia.

Figure 12 shows seasonal trends of consecutive wet days (CWD) over West Africa. For all seasons there is a mix of upward and downward trends over West Africa. These trends vary from -10 day/decade to 8 day/decade for DJF season, while for MAM, they vary from -8 days/decade to 8 days/decade. For JJA, the magnitude trends vary from -10 days/decade to 20 days/decade, while for SON season trends vary from -10 days/decade to 18 days/decade.

For DJF, downward trends are observed over West Africa excepted northern Malia and Niger, over some areas of Nigeria and over Liberia, Sierra Leone and eastern of Guinea where upward trends are found. Statistically significant downward at 5\% confident level trends are located in Ivory Coast, middlewest Cameroon, in a few areas of middle Nigeria and Niger, while statistically significant upward trends are found over northern Malia and Niger, eastern Sierra Leone, wesrtern Liberia and southeastern Nigeria. MAM and JJA seasons are dominated by upward trends which are statistically significant over southeastern Nigeria. However, non-significant increase trends are detected over some areas of coastal regions. For SON season, downward trends are found in most part of the study area. These downward trends are statistically significant over eastern of Algeria and Mauritania, middle of Malia and Niger. However, statistically significant upward trends are found over northern Malia and Niger and over Liberia.

Figure 13 shows seasonal trends of consecutive dry days (CDD) over West Africa. For all seasons there is a mix of upward and downward trends over West Africa. These trends vary from -4 days/decade to 5 days/decade for DJF season, while for MAM, they vary from -0.5 day/decade to 0.5 days/decade. For JJA, the magnitude trends vary from -2 days/decade to 1 days/decade, while for SON
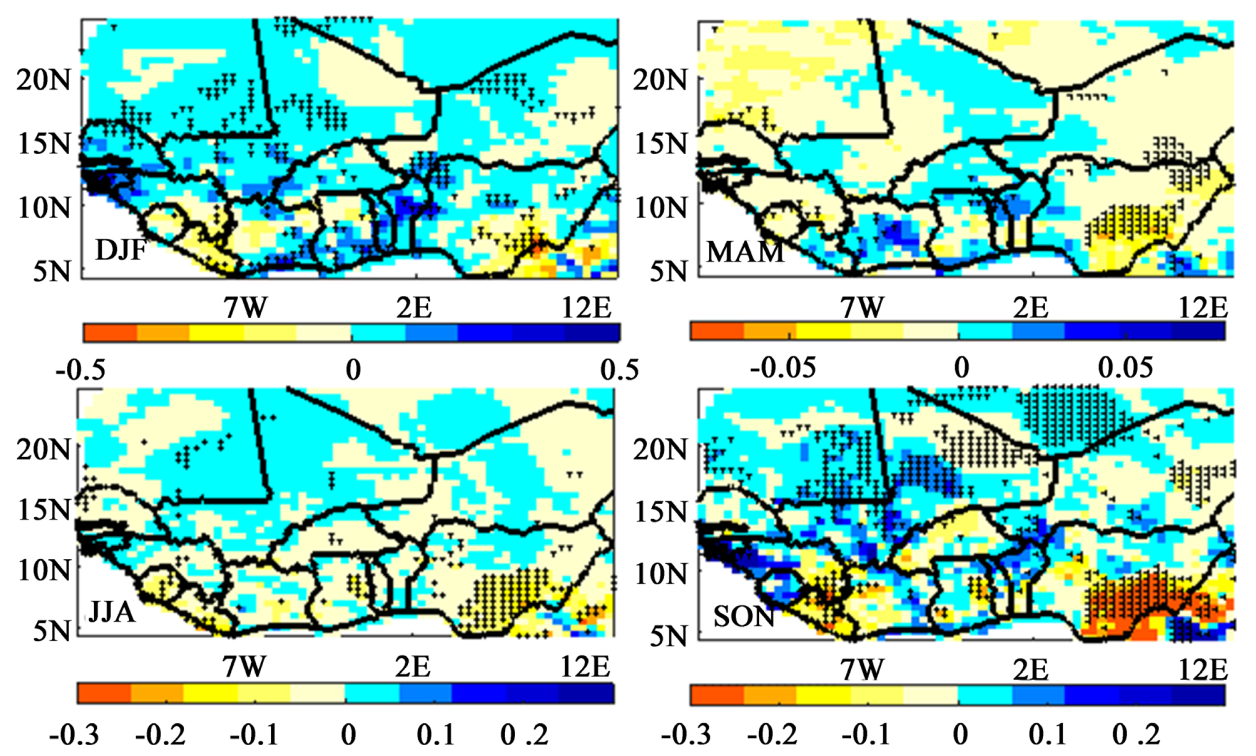

Figure 12. Trends in consecutive wet days (days/decade) in West Africa over the period 1980 to 2018. Hatching indicates regions where trends are significant at the $95 \%$ confidence level. 


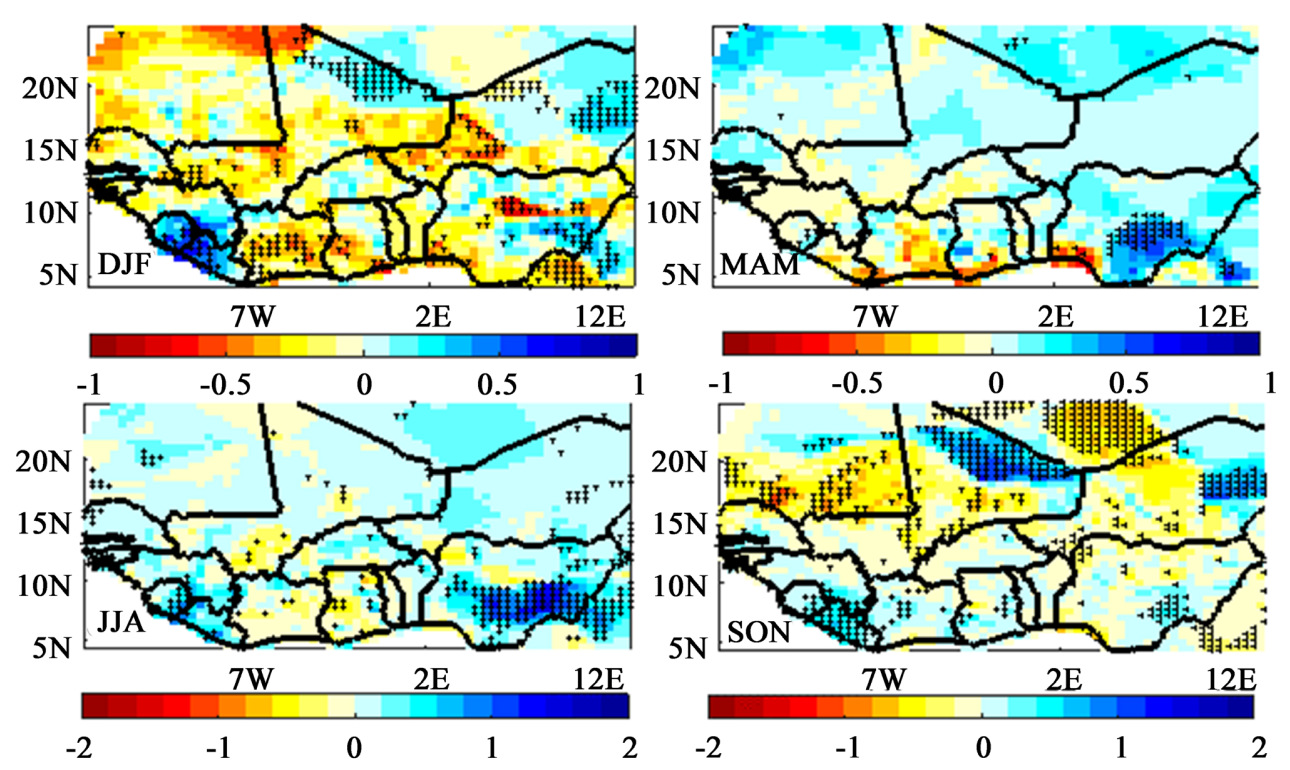

Figure 13. Trends in consecutive dry days (days/decade) in West Africa over the period 1980 to 2018. Hatching indicates regions where trends are significant at the $95 \%$ confidence level.

season trends vary from -3 days/decade to 2 days/decade.

For DJF season, upward trends are dominated over the study area. These upward trends are statistically significant over the Sahel. Some statistically significant downward trends are observed over southern Nigeria. A mix of downward and upward trends are indicated for both MAM and JJA seasons. Only downward trends are statistically significant over eastern Nigeria. For SON, over Sahel and Sahara statistically significant increase trends are observed excepted northern Malia which presents statistically significant downward trends. Over Gulf of Guinea countries, downward trends are mostly observed. These trends are statistically significant over southern Nigeria, Guinea and Liberia.

\subsection{Discussion}

The trends assessement indicates increasing trends of wet extreme rainfall indices (annual precipitation, Rx1day, Rx5day, SDII, R1, R20 and CWD). Indeed, increasing trends (sometimes statistically significant) are observed over Sahara and Sahel during JJA and SON seasons for annual precipitation, SDII, Rx1day and R1. Satatiscal significant increasing trends are indicated during the four seasons over Sahara and Sahel for R20, while statistically significant increasing trends are found during DJF and SON for CWD over Sahara and Sahel. These results are in line with the founding of Diatta [38] who concluded that wet indices have increasing trends over western Sahel and southern Sahel during summer season. [43] indicated an increase trends of the frequency of extreme storms in Sahel. The same conclusion has been drawn by [44] about the trends of extreme wet days. [45] investigated the annual trends in a number of extreme rainfall indices in West Africa and found that some significant increasing trends in the annual rainfall over Sahel. [46] [47] stated that wet indices have been in- 
creased over Ghana country. Trends study of RR1, CWD and SDII indicates predominated positive values in the northern Cameroon [48]. One of the consequences of the increase of wet indices over West Africa in the last decades is the increase in frequency and intensity of floods which cause several damages such as soil erosion, crop destruction, livestock destruction, displacement of populations and proliferation of waterborne diseases and loss of human life [49] [50]. For example 2009, 2010 were two of the years with occurrence of floods in many countries of West Africa (Burkina Faso, Benin, Nigeria and Niger). West Africa is very affected by climatic disturbances and their different consequences impact negatively the agricultural sector [8]. West Africa is considered to be one of the most exposed regions in the world [8] considering the quasi-rainfed nature of its agriculture. [48] showed that during extreme rainfall years, agriculture activities are disrupted. The excess or deficit in rainfall causes drops in agricultural production [48]. Therefore, increase trends in wet indices cause perturbation in agriculture and considerably affected food system and thus increase the vulnerability of West African people [51]. Crops deficience can lead to food insecurity which can affect the achievement of sustainable developement goals. However, statistically significant decrease trends in wet indices are often observed in soutehern West Africa particulary over southern Nigeria, Sierra Leone and Liberia. This result is in agreement with [52] who indicated a decrease in the trends in the number of very wet days in the Guinea Conakry.

The increasing trends in the number of consecutive dry days are observed during the JJA and MAM seasons unlike the DJF and SON seasons which show decreasing consecutive dry day trends. The fact that the MAM and especially JJA seasons indicate increasing trends in the number of consecutive dry days suggests that droughts due to global warming are observed with severe consequences on water availability, energy supply, agricultural yields and ecosystems of the West African [53].

Therefore, to prevent the consequences of extreme rainfall trands on environment and human health some adaptive strategies have been proposed. These are:

- Water harvesting and conservation

Several techniques are proposed for reducing of runoff coefficient of rainfall events in order to reduce the frequency and intensity of floods. This will involve promoting rain collection systems at homes (gutters and citerns), building small water reservoirs at village and district levels to develop agricultural production and livestock in dry conditions. The presence of these reservoirs can also promote infiltration and groundwater recharge. It is also important to promote multifonction hydropower building in transboundary rivers to mitigate floods frequency and intensity, to developp irrigated agriculture and to improve energy supply.

- Soil erosion mitigation

We suggest small arrangements in order to slow down the speed of the flow. 
These arrangements can be reforestation areas using trees, such as oil palm and cailcedrat or fodder species such as panicum and mucuna. Other arrangements such as bunds or the orientation of the furrows perpendicular to the direction of runoff are also recommended.

- Capacity building of agriculture and sharing of experiences

Farmers must be regularly trained on one hand on possible disruptions in the agricultural calendar due to the impact of climate change and on the other hand on cultivation tech-niques such as off-season crops, irrigation. Bearing this in mind, we recommend strength-ening the seasonal forecasting capacity of the National Meteorological Agency in order to impact many farmers as much as possible. The creation of experience-sharing crucibles is between farmers, researchers and police-makers.

- Improved land-use and natural resource management policies and institutions

This will involve adopting laws to facilitate access to land and also to separate agricultural land from the corridors of livestock transhumance.

\section{Conclusions}

The aim of this research is to analyze the intra-seasonal variability of the 39-years rainfall series (1980-2018) and to assess the resulting trends by applying the Mann-Kendall test. To achieve this goal, 8 extreme climate indices were chosen and then compared in pairs depending on the type of index before finishing by calculating the trends with the test selected.

The results obtained show that whatever the season, the South of West Africa is more watered than the North. This is due to the fact that the south of West Africa is a coastal part and is therefore under the influence of evaporation observed at the level of the Atlantic Ocean and the monsoon while the part is dominated by the desert. In addition, the trends assessment indicates increasing trends of wet extreme rainfall indices (annual precipitation, Rx1day, Rx5day, SDII, R1, R20 and CWD). Indeed, statistically significant increasing trends are observed over Sahara and Sahel during JJA and SON seasons for annual precipitation, SDII, Rx1day and R1. Statistically significant increasing trends are indicated during the four seasons over Sahara and Sahel for R20, while statistically significant increasing trends are found during DJF and SON for CWD over Sahara and Sahel. The fact that the MAM and especially JJA seasons indicate increasing trends in the number of consecutive dry days suggests that droughts due to global warming could be observed and could have severe consequences in terms of water availability, energy supply, agricultural yields and ecosystems of the West African. In addition, it can lead to the loss of biodiversity and health issues. That is why it is essential for policymakers or decisions makers to determine strategies and mitigation measures against climate change and its impacts on population. Our propositions in discussion can be taken like recommendations for decisions makers for the usefulness of this study. It is also better to in- 
vestigate with some climate models, the multi-modelisation that can fit for migration by a simple and cheaper method for West Africa.

\section{Conflicts of Interest}

The authors declare no conflicts of interest regarding the publication of this paper.

\section{References}

[1] WMO (2007) WMO Statement on the Status of the Global Climate in 2007. World Meteorological Organization, No. 1108.

http://www.wmo.int/pages/mediacentre/press_releases/documents/WMO_1108_E N_web_000.pdf

[2] L'Hôte, Y., Mahé, G., Somé, B. and Triboulet, J.P. (2002) Analysis of a Sahelian Annual Rainfall Index from 1896 to 2000; the Drought Continues. Hydrological Sciences Journal, 47, 563-572. https://doi.org/10.1080/02626660209492960

[3] Lebel, T. and Ali, A. (2009) Recent Trends in the Central and Western Sahel Regime (1990-2007). Journal of Hydrology, 375, 52-64. https://doi.org/10.1016/j.jhydrol.2008.11.030

[4] Thierry, L., Bernard, C., Sylvie, G., Hanan, N., Kergoat, L., Levis, S., Vieux, B., et al. (2009) AMMA-CATCH Studies in the Sahelian Region of West-Africa: An Overview. Journal of Hydrology, 375, 3-13. https://doi.org/10.1016/j.jhydrol.2009.03.020

[5] Mahé, G. and Paturel, J.-E. (2009) 1896-2006 Sahelian Annual Rainfall Variability and Runoff Increase of Sahelian Rivers. Comptes Rendus Geoscience, 341, 538-546. https://doi.org/10.1016/j.crte.2009.05.002

[6] Descroix, L., Niang, D., Dacosta, H., Panthou, G., Quantin, G. and Diedhou, A. (2013) Évolution des pluies de cumul élevé et recrudescence des crues depuis 1951 dans le bassin du Niger moyen (Sahel). Climatologie, 10, 37-49.

https://doi.org/10.4267/climatologie.78

[7] Panthou, G., Vischel, T. and Lebel, T. (2014) Recent Trends in the Regime of Extreme Rainfall in the Central Sahel. International Journal of Climatology, 34, 3998-4006. https://doi.org/10.1002/joc.3984

[8] GIEC (2014) Changements Climatiques 2014. In Medicine Meets Engineering (Vol. 133).

[9] Kouamé, K.J., Jourda, J.P., Saley, M.B., Deh, S.K., Anani, A.T., Leblanc, Y., Cloutier, V. and Biémi, J. (2013) Modeling of Groundwater Flow and Drawdown Evolution Simulation of Abidjan Aquifer (Côte d'Ivoire). Journal of Asian Scientific Research, 3, 344-364.

[10] Li, Y., He, D., Hu, J. and Cao, J. (2015) Variability of Extreme Precipitation over Yunnan Province, China 1960-2012. International Journal of Climatology, 35, 245-258. https://doi.org/10.1002/joc.3977

[11] Alexander, L.V., Zhang, X., Peterson, T.C., Caesar, J., Gleason, B., Klein Tank, A.M.G., Haylock, M., Collins, D., Trewin, B., Rahimzadeh, F., Tagipour, A., Rupa Kumar, K., Revadekar, J., Griffiths, G., Vincent, L., Stephenson, D.B., Burn, J., Aguilar, E., Brunet, M., Taylor, M., New, M., Zhai, P., Rusticucci, M. and VazquezAguirre, J. (2006) Global Observed Changes in Daily Climate Extremes of Temperature and Precipitation. Journal of Geophysical Research, 111, D05109. https://doi.org/10.1029/2005JD006290

[12] Acero, F.J., García, A.J. and Gallego, C.M. (2011) Peaks-over-Threshold Study of 
Trends in Extreme Rainfall over the Iberian Penísula. Journal of Climate, 24, 1089-1105. https://doi.org/10.1175/2010JCLI3627.1

[13] Panthou, G. (2013) Analyse des extrêmes pluviométriques en Afrique de l'Ouest et de leur évolution au cours des 60 dernières années. PhD Thesis, Université de Grenoble, Grenoble.

[14] Pedron, T.I., Silva Dias, M.A.F., de Paula Dias, S., Carvalho, V.M.L. and Freitas, D.E. (2016) Trends and Variability in Extremes of Precipitation in Curitiba-Southern Brazil. International Journal of Climatology, 37, 1250-1264. https://doi.org/10.1002/joc.4773

[15] Donat, M.G., Peterson, T.C., Brunet, M., King, A.D., Almazroui, M., Kolli, R.K., Boucherf, D., Al-Mulla, A.Y., Nour, A.Y., Aly, A.A., Nada, T.A.A., Semawi, M.M., Al Dashti, H.A., Salhab, T.G., El Fadli, K.I., Muftah, M.K., Dah Eida, S., Badi, W., Driouech, F., El Rhaz, K., Abubaker, M.J.Y., Ghulam, A.S., Erayah, A.S., Mansour, M.B., Alabdouli, W.O., Al Dhanhani, J.S. and Al Shekaili, M.N. (2013) Changes in Extreme Temperature and Precipitation in the Arab Region: Long-Term Trends and Variability Related to ENSO and NAO. International Journal of Climatology, 34, 581-592. https://doi.org/10.1002/joc.3707

[16] Diatta, S., Diedhiou, C.W., Dione, D.M. and Sambou, S. (2020) Spatial Variation and Trend of Extreme Precipitation in West Africa and Teleconnections with Remote Indices. Atmosphere, 11, Article No. 999.

https://doi.org/10.3390/atmos11090999

[17] Klassou, K.S. and Komi, K. (2021) Analysis of Extreme Rainfall in Oti River Basin (West Africa). Journal of Water and Climate Change, 12, 1997-2009.

https://doi.org/10.2166/wcc.2021.154

[18] Katz, R.W. and Brown, B.G. (1992) Extreme Events in a Changing Climate: Variability Is More Important than Averages. Climatic Change, 21, 289-302. https://doi.org/10.1007/BF00139728

[19] Ardoin, S., Lubes-Niel, H., Servat, E., Dezetter, A., Boyer, J.F., Mahé, G. and Paturel, J.E. (2003) Analyse de la persistance de la sécheresse en Afrique de l'Ouest: Caractérisation de la situation de la décennie 1990. In: Servat, E., Najem, W., Leduc, C. and Shakeel, A., Eds., Hydrology of the Mediterranean and Semiarid Regions, IAHS Publ. 278, IAHS Press, Wallingford, 223-228.

[20] Faye, C. (2013) Évaluation et gestion intégrée des ressources en eau dans un contexte de variabilité hydroclimatique: Cas du bassin versant de la Falémé. Thèse de doctorat, Université Cheikh Anta Diop de Dakar, Dakar, $309 \mathrm{p}$

[21] Kouassi, A.M., Nassa, R.A.K., Koffi, Y.B., Kouame, K.F. and Biemi, J. (2018) Modélisation statistique des pluies maximales annuelles dans le District d'Abidjan (sud de la Côte d'Ivoire). Revue Des Sciences De L'Eau, 31, 147-160.

https://doi.org/10.7202/1051697ar

[22] Lafore, J.P., et al. (2010) Introduction to the AMMA Special Issue on "Advances in Understanding Atmospheric Processes over West Africa through the AMMA Field Campaign”. Quarterly Journal of the Royal Meteorological Society, 136, 2-7. https://doi.org/10.1002/qj.583

[23] Servat, É., Paturel, J.E., Lubès-Niel, H., Kouamé, B., Masson, J.M., Travaglio, M. and Marieu, B. (1999) De différents aspects de la variabilité de la pluviométrie en Afrique de l'Ouest et Centrale non sahélienne. Revue des sciences de P eau/Journal of Water Science, 12, 363-387. https://doi.org/10.7202/705356ar

[24] Sow, A.A. (2007) L'hydrologie du Sud-est du Sénégal et de ses Confins guinéomaliens: Les bassins de la Gambie et de la Falémé. Thèse de doctorat d'État, Université 
Cheikh Anta Diop de Dakar, Dakar, 1232 p.

[25] Le Lay, M. and Galle, S. (2005) Seasonal Cycle and Interannual Variability of Rainfall at Hydrological Scales. The West African Monsoon in a Sudanese Climate. Hydrological Sciences Journall Journal des Sciences Hydrologiques, 50, 509-524. https://doi.org/10.1623/hysj.50.3.509.65029

[26] Chede, F.D., Ibouraïma, Y. and Constant, H. (2020) Variabilité Intra-saisonnière De La Grande Saison Pluvieuse Dans Le Sud-Benin. European Scientific Journal, ESJ, 16, Article No. 300. https://doi.org/10.19044/esj.2020.v16n6p300

[27] M'Po, N.Y., Lawin, A.E., Yao, K.B., Oyerinde, T.G., Attogouinon, A. and Afouda, A.A. (2017) Decreasing Past and Mid-Century Rainfall Indices over the Ouémé River Basin, Benin (West Africa). Climate, 5, Article No. 74.

https://doi.org/10.3390/cli5030074

[28] Conway, G. (2007) The Science of Climate Change in Africa: Impacts and Adaptation the Science of Climate Change in Africa: Impacts and Adaptation Gordon Conway Chief Scientific Adviser Department for International Development.

[29] Eltahir, E.A.B. and Gong, C. (1996) Dynamics of Wet and Dry Years in West Africa. Journal of Climate, $9,1030-1042$. https://doi.org/10.1175/1520-0442(1996)009<1030:DOWADY>2.0.CO;2

[30] Weldeab, S., et al. (2007) 155,000 Years of West African Monsoon and Ocean Thermal Evolution. Science, 316, 1303-1307.

https://doi.org/10.1126/science.1140461

[31] Kottek, M., Grieser, J., Beck, C., Rudolf, B. and Rubel, F. (2006) World Map of the Köppen-Geiger Climate Classification Updated. Meteorologische Zeitschrift, 15, 259-263. https://doi.org/10.1127/0941-2948/2006/0130

[32] Zhang, X., Alexander, L., Hegerl, G.C., Jones, P., Tank, A.K., Peterson, T.C., Trewin, B. and Zwiers, F.W. (2011) Indices for Monitoring Changes in Extremes Based on Daily Temperature and Precipitation Data, WIREs. Climatic Change, 2, 851-870. https://doi.org/10.1002/wcc.147

[33] New, M., Hewitson, B., Stephenson, D.B., Tsiga, A., Kruger, A., Manhique, A., Gomez, B., Coelho, C.A., Masisi, D.N. and Kululanga, E. (2006) Evidence of Trends in Daily Climate Extremes over Southern and West Africa. Journal of Geophysical Research, 111, D14102. https://doi.org/10.1029/2005JD006289

[34] Peterson, T.C., Taylor, M.A., Demeritte, R., Duncombe, D.L., Burton, S., Thompson, F., Porter, A., Mercedes, M., Villegas, E., Semexant, F.R., Klein, Tank, A., Martis, A., Warner, R., Joyette, A., Mills, W., Alexander, L. and Gleason, B. (2002) Recent Changes in Climate Extremes in the Caribbean Region. Journal of Geophysical Research, 107, Article No. ACL 16-1-ACL 16-9.

https://doi.org/10.1029/2002JD002251

[35] Vincent, L.A., Peterson, T.C., Barros, V.R., Marino, M.B., Rusticucci, M., Carrasco, G., Ramirez, E., Alves, L.M., Ambrizzi, T., Berlato, M.A., Grimm, A.M., Marengo, J.A., Molion, L., Moncunill, D.F., Rebello, E., Anunciação, Y.M.T., Quintana, J., Santos, J.L., Baez, J., Coronel, G., Garcia, J., Trebejo, I., Bidegain, M., Haylock, M.R. and Karoly, D. (2005) Observed Trends in Indices of Daily Temperature Extremes in South America 1960-2000. Journal of Climate, 18, 5011-5023. https://doi.org/10.1175/JCLI3589.1

[36] Christensen, A.J., Ehlers, S.L., Wiebe, J.S., Moran, P.J., Raichle, K. and Ferneyhough, K.L.W. (2002) Patient Personality and Mortality: A 4-Year Prospective Examination of Chronic Renal Insufficiency. Health Psychology, 21, 315-320. https://doi.org/10.1037/0278-6133.21.4.315 
[37] Drobinski, P., Da Silva, N., Panthou, G., Bastin, S., Muller, C., Ahrens, B., Borga, M., Conte, D., Fosser, G., Giorgi, F., Güttler, I., Kotroni, V., Li, L., Morin, E., Onol, B., Quintana Seguí, P., Romera, R. and Torma, C. (2018) Temperature-Precipitation Extremes Relationship in the Mediterranean: Past Climate Assessment and Projection in Anthropogenic Scenarios. Climate Dynamics, 51, 1237-1257. https://doi.org/10.1007/s00382-016-3083-x

[38] Bera, S. (2017) Trend Analysis of Rainfall in Ganga Basin, India during 1901-2000. American Journal of Climate Change, 6, 116-131.

https://doi.org/10.4236/ajcc.2017.61007

[39] Obada, E., Alamou, A.E., Chabi, A., Zandagba, J. and Afouda, A. (2017) Trends and Changes in Recent and Future Penman-Monteith Potential Evapotranspiration in Benin (West Africa). Hydrology, 4, Article No. 38.

https://doi.org/10.3390/hydrology4030038

[40] Partal, T. and Kahya, E. (2006) Trend Analysis in Turkish Precipitation Data. Hydrological Processes, 20, 2011-2026. https://doi.org/10.1002/hyp.5993

[41] Jaagus, J. (2006) Trends in Sea Ice Conditions in the Baltic Sea near the Estonia, Coast during the Period 1949/1950-2003/2004 and Their Relationships to Large Scale Atmospheric Circulation. Boreal Environment Research, 11, 169-183.

[42] Amoussou, E., Awoye, H., Vodounon, T.S.H., Obahoundje, S., Camberlin, P., Diedhiou, A., Kouadio, K., Mahé, G., Houndénou, C. and Boko, M. (2020) Climate and Extreme Rainfall Events in the Mono River Basin (West Africa): Investigating Future Changes with Regional Climate Models. Water, 12, Article No. 833. https://doi.org/10.3390/w12030833

[43] Taylor, C., Belusic, D., Guichard, F., Parker, D., Vischel, T., Bock, O., Harris, P., Janicot, S., Klein, C. and Panthou, G. (2017) Frequency of Extreme Sahelian Storms Tripled since 1982 in Satellite Observations. Nature, 544, 475-478. https://doi.org/10.1038/nature22069

[44] Adedoyin, A., et al. (2005) Evaluating the National Center for Atmospheric Research Climate System Model over West Africa: Present-Day and the 21st Century A1 Scenario. Journal of Geophysical Research (Atmospheres), 110, 18 p. https://doi.org/10.1029/2004JD004689

[45] Odoulami, R.C. and Akinsanola, A.A. (2018) Recent Assessment of West African Summer Monsoon Daily Rainfall Trends. Weather, 73, 283-287. https://doi.org/10.1002/wea.2965

[46] Sanogo, S., Fink, A.H., Omotosho, J.A., Ba, A., Redl, R. and Ermert, V. (2015) Spatio-Temporal Characteristics of the Recent Rainfall Recovery in West Africa. International Journal of Climatology, 35, 4589-4605. https://doi.org/10.1002/joc.4309

[47] Tabari, H. and Talaee, P.H. (2011) Temporal Variability of Precipitation over Iran: 1966-2005. Journal of Hydrology, 396, 313-320.

https://doi.org/10.1016/j.jhydrol.2010.11.034

[48] Atiah, W.A., Tsidu, G.M., Amekudzi, L.K. and Yorke, C. (2020) Trends and Interannual Variability of Extreme Rainfall Indices over Ghana, West Africa. Theoretical and Applied Climatology, 140, 1393-1407.

https://doi.org/10.1007/s00704-020-03114-6

[49] Voundou, D.A., Guenang, G.M., Djiotang, T.L.A. and Kamsu-Tamo, P.H. (2021) Trends and Interannual Variability of Extreme Rainfall Indices over Cameroon. Sustainability, 13, Article No. 6803. https://doi.org/10.3390/su13126803

[50] Yabi, I. and Afouda, F. (2012) Extreme Rainfall Years in Benin (West Africa). Quaternary International, 262, 39-43. https://doi.org/10.1016/j.quaint.2010.12.010 
[51] Nicholson, S. (2005) On the Question of the "Recovery" of the Rains in the West African Sahel. Journal of Arid Environments, 63, 615-641. https://doi.org/10.1016/j.jaridenv.2005.03.004

[52] Aguilar, E., Barry, A.A., Brunet, M., Ekang, L., Fernandes, A., Massoukina, M. Mbah, J., Mhanda, A., do Nascimento, D.J., Peterson, T.C., Umba, T.O., Tomou, M. and Zhang, X. (2009) Changes in Temperature and Precipitation Extremes in Western Central Africa, Guinea Conakry, and Zimbabwe, 1955-2006. Journal of Geophysical Research, 114, D02115. https://doi.org/10.1029/2008JD011010

[53] Paturel, J.E., Ouedraogo, M., Servat, E., Mahe, G., Dezetter, A. and Boyer, J.F. (2003) The Concept of Rainfall and Streamflow Normals in West and Central Africa in a Context of Climatic Variability. Hydrological Sciences Journal, 48, 125-137. https://doi.org/10.1623/hysj.48.1.125.43479 